\title{
A study on depression in people living with HIVIAIDS in South-West part of Uttar Pradesh, India
}

\author{
Preeti Rai ${ }^{1}$, Babu L Verma ${ }^{2}$
}

${ }^{1}$ Former Resident, Department of Community Medicine; ${ }^{2}$ Former Professor of Biostatistics and In-Charge, Division of Biostatistics; Maharani Laxmi Bai Medical College \&Hospital, Jhansi (Uttar Pradesh), India.

\begin{abstract}
HIV/AIDS and depression are often thought to be interlinked. HIV positive cases may trigger symptoms of depression which, in turn, may result in risky sexual behavior and spread of HIV. Interviews were conducted in 104 patients of HIV/AIDS at the Anti-Retroviral Therapy (ART) Clinic of a teaching hospital in Uttar Pradesh (India) to study depression and examine its prevalence and association, if any, with some socio-demographic and clinical variables. The tools used to assess anxiety and depression and their severities were General Health Questionnaire (GHQ) 28 and Montgomery-Asberg Depression Rating Scale (MADRS). The majority of patients were of age 35 years \& above $(62 \%)$, males $(67 \%)$, married $(85 \%)$, Hindus $(88 \%)$, literate $(73.1 \%)$, unemployed $(35 \%)$ and of upper-lower socio-economic status (52\%). Significant association of depression was found with religion, occupation and socio-economic status. Depression and anxiety were also found to be significantly associated with each other. There was, however, no association of depression with respondents' age, gender, marital status, education, habitat, income, duration of illness from HIV/AIDS and the CD4 count. The high prevalence rate (67.3\%) of depression amongst HIV patients in our study may be taken as marker to alert Counsellors of country's ART Clinics for possible risk of depression in HIV patients. The above findings however, should be interpreted in the light of the fact that a parallel control group in the study was not included, studied sample was not large enough and the tools used to study the subjects for depression and anxiety were not adequately standardized.
\end{abstract}

Keywords: HIV/AIDS, Depression, Anxiety, PLHAs, India.

\section{Introduction}

Depression is one of the major disabling factors in chronic illnesses. ${ }^{1}$ It is most extensively studied psychiatric co-morbidity, affecting HIV-infected patients, with estimates of lifetime prevalence rates - ranging from $4 \%$ to $45 \%{ }^{2}$ Further, reasons for high prevalence of depression amongst people living with HIV/AIDS (PLHAs) could be many. ${ }^{2,3,4} \mathrm{HIV}$ is a chronic and lifethreatening illness and, like other such illnesses, can be stressful to manage. ${ }^{1}$ Its life-threatening nature may lead to fears of impending mortality. Moreover, medical sequel of HIV infection, its associated opportunistic infections and side effects of antiretroviral treatment can mimic symptoms of depression (viz. fatigue, concentration problems, somatic symptoms, decreased appetite \& weight loss etc). ${ }^{5}$ On the other hand, several psychiatric conditions including depression may predispose individuals to acquiring HIV infection as a consequence of their influence on behavior. ${ }^{6,7}$

There is good evidence from the international research particularly from developed countries, that the prevalence of depression in PLHAs is higher than those with HIVnegative controls. ${ }^{8,9}$ However, very little is known about their mental problems and subsequent needs in developing countries like India, which are most affected by the HIV-epidemic. ${ }^{10,11}$ Incidentally, minimal research on this subject has been done in this part of the globe. The present study was designed to estimate prevalence of

\section{Practice Points}

- HIV is a chronic and life-threatening illness. Its positive diagnosis may trigger symptoms of depression, which may, in turn, result in their risky sexual behavior and contribute to further spread of HIV.

- In India, available data suggests that depression is under-recognized and under-treated in HIVinfected individuals.

- The study recorded an overall prevalence rate of depression amongst PLHAs as $67.3 \%$. The majority of HIV/AIDS patients were either moderately or severely depressed (52.9\%). Significant association of depression was detected with religion, individual occupation and socio-economic status only.

- The prevalence of anxiety among respondents was found to be $76.9 \%$ and $55.8 \%$ had both anxiety and depression. The association between depression and anxiety was found to be statistically significant.

- The high prevalence of depression amongst HIV/AIDS patients may be taken as a marker to alert Counselors of country's ART Centers for possible risk of depression in HIV patients.

Correspondence: Dr Preeti Rai, Former Resident, Department of Community Medicine, Maharani Laxmi Bai Medical College \& Hospital, Jhansi - 284128 (Uttar Pradesh), India. Email: preeti.rai1708@gmail.com. 
depression amongst HIV/AIDS patients and look into its association with their socio-demographic and clinical variables. Results of this study may help bridging the existing gap in the knowledge and provide a baseline for planning and program development for the PLHAs at ART Centers of the country.

\section{Materials and Methods}

This cross-sectional study was undertaken at ART Clinic of Maharani Laxmi Bai Medical College \& Hospital, Jhansi (UP), India. HIV/AIDS patients registered at the above Clinic - both males \& females and aged 18 years and above, were recruited as the study participants. Sample size, using method of Lwanga \& Lameshow ${ }^{12}$ was estimated to be 96 . Giving an allowance for refusal rate, 104 participants, on safer side, were selected, following Systematic Sampling. The study period was from 1 April 2013 to 31 March 2014. Socio-demographic and clinical profiles of respondents were completed by interviewing each participant separately, using pretested questionnaire. The socio-economic status of respondents was assessed using Modified Kuppuswamy Scale ${ }^{13}$. Anxiety as well as depression and their severities were studied, using interview method, applying General Health Questionnaire (GHQ) 28 tool $^{14}$ and MontgomeryAsberg Depression Rating Scale (MADRS) tool. ${ }^{15}$ Data were analyzed using SPSS version 16. The study had the necessary clearance from the institutional Ethical Committee.

\section{Results}

Socio-demographic characteristics

The socio-demographic characteristics of the respondents are shown in Table 1. Majority of the respondents $(61.54 \%)$ were aged 35 years and more, males $(67.3 \%)$, married $(84.6 \%)$ and Hindus $(88.5 \%)$. More than half $(56.7 \%)$ of the respondents were from rural habitat, $73 \%$ were literate, and $34.6 \%$ respondents were unemployed. Earnings of the most of the respondents (51.93\%) ranged between Indian Rs. 1,601Rs. 8,009 per month, with majority belonging to the upper-lower socio-economic status. ${ }^{13}$

\section{Clinical history}

The clinical history of the respondents is included in Table 2. All patients of the ART Clinic were referred by a Medical Doctor for treatment. Only 4 cases $(3.8 \%)$ had consulted a Psychiatrist for their ailments. More than half of respondents (57.6\%) were detected as HIVpositive at the ART Clinic during past 3 years and $63.46 \%$ of the respondents had CD 4 count $\leq 300$. They frequently $(78.8 \%)$ reported heterosexuality as possible route for HIV transmission, followed by blood transfusion $(9.6 \%)$, unsafe injection $(6.7 \%)$ and homosexuality $(2.9 \%)$.

\section{Depression and anxiety}

Depression as well as anxiety levels in the studied PLHAs are shown in Table 3. Prevalence rate of anxiety in our study was found to be $76.9 \%$ against $67.3 \%$ for depression. Majority of patients were either moderately or severely depressed $(52.9 \%)$. It may be relevant to indicate here that, with a chronic condition like HIV, depression can fuel additional problems, such as failure to take life-saving antiretroviral medications. When depression is paired with HIV, the two diseases can feed off of one another.

Table 1: Socio-demographic characteristics of study subjects

\begin{tabular}{|c|c|}
\hline Variables & $\begin{array}{c}\text { Respondents } \\
\text { (n-104) }\end{array}$ \\
\hline \multicolumn{2}{|l|}{ Age (years) } \\
\hline$<35$ & $40(38.46 \%)$ \\
\hline$\geq 35$ & $64(61.54 \%)$ \\
\hline \multicolumn{2}{|l|}{ Gender } \\
\hline Female & $34(32.69 \%)$ \\
\hline Male & $70(67.31 \%)$ \\
\hline \multicolumn{2}{|l|}{ Marital Status } \\
\hline Married & $88(84.62 \%)$ \\
\hline Unmarried & $12(11.54 \%)$ \\
\hline Widow & $4(3.84 \%)$ \\
\hline \multicolumn{2}{|l|}{ Religion } \\
\hline Hindu & $92(88.46 \%)$ \\
\hline Muslim & $12(11.54 \%)$ \\
\hline \multicolumn{2}{|l|}{ Caste } \\
\hline General & $44(42.30 \%)$ \\
\hline $\mathrm{OBC}$ & $30(28.85 \%)$ \\
\hline $\mathrm{SC}$ & $30(28.85 \%)$ \\
\hline \multicolumn{2}{|l|}{ Habitat } \\
\hline Rural & $59(56.73 \%)$ \\
\hline Urban & $45(43.27 \%)$ \\
\hline \multicolumn{2}{|l|}{ Education } \\
\hline Illiterate & $28(26.92 \%)$ \\
\hline Primary & $17(16.35 \%)$ \\
\hline Middle & $14(13.46 \%)$ \\
\hline High school & $11(10.57 \%)$ \\
\hline Intermediate & $12(11.55 \%)$ \\
\hline Graduate/Postgraduate & $22(21.15 \%)$ \\
\hline \multicolumn{2}{|l|}{ Occupation(Individual) } \\
\hline Unemployed & $36(34.62 \%)$ \\
\hline Unskilled & $33(31.73 \%)$ \\
\hline Semiskilled & $12(11.55 \%)$ \\
\hline Skilled & $2(1.91 \%)$ \\
\hline Clerical & $7(6.73 \%)$ \\
\hline Semi professional & $12(11.55 \%)$ \\
\hline Professional & $2(1.91 \%)$ \\
\hline \multicolumn{2}{|c|}{ Monthly Income (Indian Rupees) } \\
\hline$\leq 1600$ & $5(4.80 \%)$ \\
\hline $1601-4809$ & $28(26.93 \%)$ \\
\hline $4810-8009$ & $26(25.00 \%)$ \\
\hline $8010-12019$ & $18(17.31 \%)$ \\
\hline $12020-16019$ & $8(7.69 \%)$ \\
\hline $16020-32049$ & $10(9.62 \%)$ \\
\hline$\geq 32050$ & $9(8.65 \%)$ \\
\hline \multicolumn{2}{|l|}{ Socioeconomic status } \\
\hline Lower & $6(5.76 \%)$ \\
\hline Upper lower & $54(51.93 \%)$ \\
\hline Lower middle & $25(24.05 \%)$ \\
\hline Upper middle & $17(16.35 \%)$ \\
\hline Upper & $2(1.91 \%)$ \\
\hline
\end{tabular}


Table 2: Clinical history of study subjects

\begin{tabular}{|l|c|}
\hline \multicolumn{1}{|c|}{ Variables } & $\begin{array}{c}\text { Respondents } \\
(\mathrm{n}-104)\end{array}$ \\
\hline Source of referral \\
\hline Doctor & $97(93.27 \%)$ \\
\hline Family/friend & $2(1.93 \%)$ \\
\hline Own & $5(4.81 \%)$ \\
\hline Consulted a psychiatrist \\
\hline No \\
\hline Yes & $100(96.15 \%)$ \\
\hline CD4 count & $4(3.85 \%)$ \\
\hline$\leq 300$ & $66(63.46 \%)$ \\
\hline$>300$ & $38(36.54 \%)$ \\
\hline Duration of illness \\
\hline$<3$ years & $60(57.69 \%)$ \\
\hline$\geq 3$ years & $44(42.31 \%)$ \\
\hline HIV transmission \\
\hline Heterosexual & $82(78.85 \%)$ \\
\hline Blood transfusion & $10(9.62 \%)$ \\
\hline Unsafe injection & $7(6.73 \%)$ \\
\hline Homosexual & $3(2.88 \%)$ \\
\hline Unknown & $2(1.92 \%)$ \\
\hline
\end{tabular}

Table 3: Levels of depression and anxiety in PLHAs

\begin{tabular}{|l|c|}
\hline Psychiatric variables & $\begin{array}{c}\text { Respondents } \\
(\mathrm{n}-104)\end{array}$ \\
\hline Depression Level & $34(32.70 \%)$ \\
\hline Absent & $15(14.42 \%)$ \\
\hline Mild & $27(25.96 \%)$ \\
\hline Moderate & $28(26.92 \%)$ \\
\hline Severe \\
\hline Anxiety Level & $24(23.08 \%)$ \\
\hline Absent & $55(52.88 \%)$ \\
\hline Low & $25(24.04 \%)$ \\
\hline High
\end{tabular}

As regards association between depression and anxiety, Table 4 shows that $55.8 \%$ of respondents had anxiety as well as depression, $21.1 \%$ of respondents with anxiety were not depressed and $11.5 \%$ of respondents neither had anxiety nor depression. The association between depression and anxiety was found to be statistically highly significant $(p=0.00)$.

Depression and demographic and clinical variables When investigated for presence of depression and its association with various socio-demographic variables (Table 5), significant association of depression was detected with religion $(p=0.04)$, occupation $(p=0.01)$ and socio-economic status $(p=0.01)$. Variables like age, gender, marital status, education, habitat, income, duration of illness from HIV/AIDS and the CD4 count, did not exhibit any association with the depression.

\section{Discussion}

Depression is a major problem in HIV- infected patients, as it can lead to poor adherence to ART, treatment failure, HIV progression and death. ${ }^{16-19}$ In our study, majority of respondents were aged 35 years and more, male, married, Hindu, literate and employed. Significant association of depression was found with religion, occupation and socio-economic status. We also found significant association of depression with anxiety. However, no association of depression was seen with other socio-demographic and clinical variables considered in the study including $\mathrm{CD}_{4}$ count.

Our study further showed that $67.3 \%$ of the participants were depressed. A 2001 meta-analysis ${ }^{4}$ of studies on HIV and depression showed that people with HIV run twice the risk of depression as those who were at-risk for HIV but remained uninfected. In another Indian study, ${ }^{20}$ prevalence rates of depression among HIV sero-positive individuals were ranged from $10 \%$ to $40 \%$. In similar studies, Kaharuza et al. ${ }^{21}$ and Bhatia et al. ${ }^{22}$ found prevalence of depression to be $47 \%$ in Uganda and $45 \%$ in USA respectively. Collaborating with these reports, our findings point out that depression could be relatively frequent among HIV/AIDS patients. However, a high rate of depression in PLHAs, as seen above, should be seen in the light of the fact that a parallel control group in the present study was not included, enabling us to measure the role of HIV/AIDS in increasing risk for depression in them.

Socioeconomic factors have been reported as predisposing factors in HIV infection and have also been found to be relevant factors in depression related to HIV disease progression. ${ }^{23-24}$ The association between individual occupation and depression in our study has been found to be statistically significant. Further, around $35 \%$ of the respondents $(34.6 \%)$ were unemployed. This indicates that people who were not working were more likely to be depressed than those who had employment of some kind. These findings add to the existing evidence that unemployment predicts depression. ${ }^{25}$ This possibly is due to the fact that working PLHAs are assured of some income that would enable them AIDS' care. Another study ${ }^{26}$ from Nigeria showed that PLHAs who were unemployed were three times more depressed as compared to those who were employed (OR:2.94, $p<0.04$ ). A multivariate analysis from Uganda ${ }^{27}$ has also shown that major depressive

Table 4: Association between depression and anxiety in respondents

\begin{tabular}{|l|c|c|c|}
\hline \multirow{2}{*}{ Depression } & \multicolumn{2}{|c|}{ Anxiety } & Total \\
\cline { 2 - 4 } & Present & Absent & $70(67.31 \%)$ \\
\hline Present & $58(55.76 \%)$ & $12(11.54 \%)$ & $34(32.69 \%)$ \\
\hline Absent & $22(21.15 \%)$ & $24(11.54 \%)$ & $104(100 \%)$ \\
\hline \multicolumn{2}{|c|}{ Chi Square=4.24, d.f. $=1, p=0.039$} \\
\hline
\end{tabular}


Table 5 : Association of depression with demographic and clinical variables

\begin{tabular}{|c|c|c|c|c|c|c|}
\hline \multirow[b]{2}{*}{ Variables } & \multirow{2}{*}{$\begin{array}{l}\text { Subject } \\
\text { studied } \\
(n=104)\end{array}$} & \multicolumn{2}{|c|}{ Depression } & \multicolumn{3}{|c|}{$\begin{array}{c}\text { Statistical significance of } \\
\text { association }\end{array}$} \\
\hline & & No & $\begin{array}{c}\text { Prevalence } \\
\text { rate }(\%)\end{array}$ & $\begin{array}{c}\text { Chi- } \\
\text { square }\end{array}$ & d f & $p$-value \\
\hline \multicolumn{7}{|l|}{ Age (years) } \\
\hline$<35$ & 40 & 24 & 60 & \multirow[t]{2}{*}{1.577} & \multirow[t]{2}{*}{1} & \multirow[t]{2}{*}{0.209} \\
\hline$\geq 35$ & 64 & 46 & 71.89 & & & \\
\hline \multicolumn{7}{|l|}{ Gender } \\
\hline Male & 70 & 44 & 62.86 & \multirow[t]{2}{*}{1.927} & \multirow[t]{2}{*}{1} & \multirow[t]{2}{*}{0.165} \\
\hline Female & 34 & 26 & 76.47 & & & \\
\hline \multicolumn{7}{|l|}{ Marital Status } \\
\hline Married/Ever married & 92 & 64 & 69.6 & \multirow[t]{2}{*}{1.847} & \multirow[t]{2}{*}{1} & \multirow[t]{2}{*}{0.174} \\
\hline Un-married & 12 & 6 & 50 & & & \\
\hline \multicolumn{7}{|l|}{ Religion } \\
\hline Hindu & 92 & 65 & 70.65 & \multirow[t]{2}{*}{4.053} & \multirow[t]{2}{*}{1} & \multirow[t]{2}{*}{$0.04^{*}$} \\
\hline Muslim & 12 & 5 & 41.67 & & & \\
\hline \multicolumn{7}{|l|}{ Education } \\
\hline Illiterate & 28 & 17 & 60.71 & \multirow[t]{2}{*}{0.757} & \multirow[t]{2}{*}{1} & \multirow[t]{2}{*}{0.384} \\
\hline Literate & 76 & 53 & 69.74 & & & \\
\hline \multicolumn{7}{|l|}{ Occupation } \\
\hline Un-occupied & 36 & 30 & 83.33 & \multirow[t]{2}{*}{6.426} & \multirow[t]{2}{*}{1} & \multirow[t]{2}{*}{$0.01 *$} \\
\hline Occupied & 68 & 40 & 58.82 & & & \\
\hline Habitat & & & & & & \\
\hline Rural & 59 & 41 & 69.5 & 0.296 & 1 & 0.587 \\
\hline Urban & 45 & 29 & 64.4 & & & \\
\hline Income (Rupees) & & & & & & \\
\hline$<5000$ & 33 & 26 & 78.8 & 2.895 & 1 & 0.089 \\
\hline$\geq 5000$ & 71 & 44 & 62 & & & \\
\hline Duration of illness & & & & & & \\
\hline$<3$ years & 60 & 40 & 66.66 & 0.026 & 1 & 0.871 \\
\hline$\geq 3$ years & 44 & 30 & 68.2 & & & \\
\hline CD4 Count & & & & & & \\
\hline$\leq 300$ & 66 & 47 & 71.21 & 1.251 & 1 & 0.263 \\
\hline$>300$ & 38 & 23 & 60.53 & & & \\
\hline Socioeconomic status & & & & & & \\
\hline Lower & 60 & 46 & 76.7 & 10.408 & 2 & $0.005^{*}$ \\
\hline Middle & 25 & 17 & 68 & & & \\
\hline Upper & 19 & 7 & 36.84 & & & \\
\hline
\end{tabular}

${ }^{*} p$-value significant, ${ }^{\dagger}$ Lower SES includes Lower and Upper- Lower, and Upper SES includes Upper - Middle and Upper SES.

disorder was significantly associated with lacking employment.

A study from Pakistan, ${ }^{28}$ where HIV was almost nonexistent, reported significant association of depression with poor socioeconomic status. This is true for depressed PLHAs in our ART Clinic participants with low socio-economic status. Such PLHAs were more depressed than those who had a higher socio-economic status. Studies have shown that emotional distress and poor socio-economic state affect people's ability to cope with HIV infection. ${ }^{29}$

Our Study further showed significant association between depression and anxiety. Such an association looks biologically plausible and so implied also. A study from India ${ }^{30}$ also showed similar relationship between anxiety and depression levels. In another similar study from India found that majority $(90 \%)$ of the patients with depressive symptoms also had prominent anxiety symptoms and fulfilled the ICD-10 criteria for generalized anxiety disorder and that, this association was found to be statistically significant. ${ }^{20}$

Our study showed no significant association between depression and age, gender, habitat, marital status, duration of HIV/AIDS and CD4 count of respondents. Almost similar results have also been found in other studies. $^{26,31,32}$ More planned studies with sufficiently large samples however, are needed to examine such hypotheses.

We can thus, see that it is essential to screen, identify, and treat depression among patients entering into ART Centers for HIV treatment. Data also suggest that depression is under-recognized and under-treated in 
HIV-infected individuals and so, further research in this part of globe is needed. Also, diagnosis and management of depression are important factors for optimal outcome of HIV/AIDS patients.

\section{Limitations of the study}

This study has some limitations. First, this was a crosssectional study, undertaken in special population group, (i.e. HIV positive people). Hence, its results on depression - particularly with regard to its prevalence rate, cannot be compared with other studies, undertaken in general populations. Secondly, tools used in this study were not adequately standardized. These have mostly been used in measuring severity of the condition. This consideration needs to be taken care of while comparing its results with other studies, undertaken in similar population groups. With qualitative and more standardized tools, this study could have yielded better results. In fact, in studies like the present one, more qualitative tools such as focused groupdiscussions are desirable as respondents often have many issues and experiences to share with the study Investigators. Thirdly, a parallel control group in this study was not considered. A high rate of depression amongst the studied PLHAs should therefore, be viewed in the light of this fact. Further, a longitudinal probe could have thrown better light on different aspects of the study, including association between psychiatric morbidity and HIV/AIDS.

\section{Conclusion}

Our findings indicate a high rate of prevalence of depression in HIV-infected people and its significant association with some demographic variables, viz. religion, individual occupation and socio-economic status. The depression was not found to be associated with age, gender, marital status, education, habitat, income, duration of illness from HIV/AIDS and $\mathrm{CD}_{4}$ count. This highlights the need of efficient mental health interventions to be integrated into HIV Care Centers in the country. A quality counseling to the HIV patients could avoid acute depression amongst them. Safe and effective treatment of depression, one of the most common co-morbid conditions in individuals infected with HIV, will significantly lower down its morbidity and mortality in the country.

\section{References}

1. Godberg D. The detection and treatment of depression in the physically ill. World Psychiatry 2010;9:16-20.

2. Himelhoch S, Moore RD, Treisman GJ, Gebo KA. Does the presence of a current psychiatric disorder in AIDS patients affect the initiation of antiretroviral treatment and duration of therapy? J Acquir Immune Defic Syndr 2004; 37:145763.

3. Bhatia MS, Munjal S. Prevalence of depression in People Living with HIV/AIDS undergoing ART and factors associated with it. $J$ Clin Diagn Res 2014, 8(10): WC01-WC04.
4. Heitz D. People with HIV suffer from depression, caused by shame, trauma, substance abuse. Healthline News, 2 September 2014.

5. Safren S, Gonzalez J, Soroudi N. Coping with Chronic Illness: A Cognitive-Behavioral Approach for Adherence and Depression. New York: Oxford University Press, 2007.

6. Stein MD, Solomon DA, Herman DS, Anderson BJ, Miller I. Depression severity and drug injection HIV risk behavior. Am J Psych, 2003;160:1659-62.

7. Woody GE, Metzger D, Navaline H, Mc Lellan T, O’Brien CP. Psychiatric symptoms, risky behavior and HIV infection. NIDA Research Monograph 1997;172:156-70.

8. Akena DH, Musisi S, Kinyanda E. A comparison of the clinical features of depression in HIV- positive and HIV-negative patients in Uganda. Afr $J$ Psychiatry (Johannesbg) $2010 ; 13: 43-51$.

9. Kaur R, Kaur R. A comparison of clinical features among patients suffering from depression in HIV positive and HIV negative cases. Del Psychiatry J 2012;15:160-4.

10. Shah B, Parhee R, Kumar N, Khanna T, Singh R. Mental Health Research in India. Technical Monograph on ICMR Mental Health Studies. New Delhi: Indian Council of Medical Research, 2005,

11. Math SB, Srinivasaraju R. Indian Psychiatric epidemiological studies: Learning from the past. Indian J Psychiatry 2010;52(Supp):95103

12. Lwanga SK, Lameshow S. Sample Size Determination in Health Studies - A Practical Manual. Geneva: World Health Organization, 2000 .

13. Bairwa M, Rajput M, Sachdeva S. Modified Kuppuswamy's socio-economic scale: Social researcher should include updated income criteria, 2012. Indian $J$ Community Med 2013;38:185-6.

14. Golderberg D, Williams P. A User Guide to General Health Questionnaire. Windsor, U K: NFER-Nelson, 1988.

15. Montgomery SA, Asberg M. A new depression scale designed to be sensitive to change. British J Psychiatry 1979;134;382-9.

16. Treisman G, Angelino A. Interrelation between psychiatric disorders and the prevention and treatment of HIV infection. Clin Infect Dis 2007;45:313-7.

17. Sternhell PS, Corr MJ. Psychiatric morbidity and adherence to antiretroviral medication in patients with HIV/AIDS. Aust NZ J Psychiatry 
2002;36:528-33.

18. Paterson DL, Swindells S, Mohr J, Brester M, Vergis EN, Squier C, Wagener MM, et al. Adherence to Protease inhibitor Therapy and outcomes in patients with HIV infection. Ann Inter Med 2000;133:21-30.

19. Leserman J. HIV Disease Progression: Depression, stress, and possible mechanisms. Biol Psychiatry 2003;54:295-306.

20. Chandra P S, Ravi V, Desai A, Subbakrishna DK. Anxiety and depression among HIVinfected heterosexuals - A report from India. $J$ Psychosom Res 1998;45:401-9.

21. Kaharuza FM, Bunnell R, Moss S, Purcell DW, Bikaako-Kajura W, Wamai N, Downing R, et al. Depression, CD4 Cell Count among persons with HIV infection in Uganda. AIDS Behav 2006 (4 suppl);10:105-11.

22. Bhatia R, Hertman C, Kallen MA, Graham J, Giordeno TP. Persons newly diagnosed with HIV Infection are at high risk of depression and poor linkage to care: Results from the Steps study. AIDS Behav 2010;8:1-10.

23. Tadios Y, Davey G. Antiretroviral treatment adherence and its correlates in Addis Ababa, Ethiopia. Ethiop Med J 2006;44:237-44.

24. Gureje O, Alem A. Mental Health Policy Development in Africa. Bull World Health Organ 2000;78:475-82.

25. Fleming CA, Christiansen D, Nunes D. Health related quality of life of patients with HIV disease: Impact of hepatitis $\mathrm{C}$ co-infection. Clin Infect Dis 2004;38:572-8.
26. Chikezie UE, Otakpor AN, Kuteyi OB, James BO. Depression among people Living with Human Immunodeficiency Virus infection/ acquired immunodeficiency Syndrome in Benin City, Nigeria: A comparative study, Niger $J$ Clin Pract 2013;16:238-42.

27. Akena D, Musisi S, Joska J, Stein DJ. The association between AIDS related stigma and major depressive disorder among HIV-positive individuals in Uganda. PLoS One 2012;7:e48671.

28. Mumford DB, Minhas F, Akhtar I, Akhtar S, Mubbashar MH. Stress and psychiatric disorder in urban Rawalpindi. British $J$ Psychiatry 2000;177:557-62.

29. Grassi L, Righi R, Sighinolfi L, Makoui S, Ghinelli F. Coping styles and psychosocialrelated variables in $\mathrm{HIV}$-infected patients. Psychosomatics 1998;39: 350-9.

30. Agrawal M, Srivastava K, Goyal S, Chaudhury S. Psychosocial correlates of Human Immunodeficiency Virus infected patients. Ind $J$ Psychiatr, 2012;21:55-60.

31. Dhadphale M, Ellison RH, Griffin L. The frequency of psychiatric disorders among patients attending semi-urban and rural general Outpatient clinics in Kenya. British J Psychiatry 1993;142:379-83.

32. Khan MA, Sharma S. Socio-demographic and clinical profile of People Living with HIV/ AIDS. Asian J Med Sci 2013;3:1-10. 